ఠ

ERRATUM

\title{
Radiofrequency-targeted vertebral augmentation versus traditional balloon kyphoplasty: radiographic and morphologic outcomes of an ex vivo biomechanical pilot study [Erratum]
}

Dalton BE, Kohm AC, Miller LE, Block JE, Poser RD. Clinical

Interventions in Aging 2012,7:525-531.

In the Disclosure section, Dr Andrew C Kohm is referred to as "AWK". This should be "ACK".

Clinical Interventions in Aging

\section{Publish your work in this journal}

Clinical Interventions in Aging is an international, peer-reviewed journal focusing on evidence-based reports on the value or lack thereof of treatments intended to prevent or delay the onset of maladaptive correlates of aging in human beings. This journal is indexed on PubMed Central, MedLine, the American Chemical Society's 'Chemical Abstracts
Service' (CAS), Scopus and the Elsevier Bibliographic databases. The manuscript management system is completely online and includes a very quick and fair peer-review system, which is all easy to use. Visit $\mathrm{http}: / /$ www.dovepress.com/testimonials.php to read real quotes from published authors. 